\section{UNAKAN: A COMBINATION OF THE IMAGES OF THAI HERO AND HEROINE ${ }^{1}$}

\section{Thaneerat Jatuthasri ${ }^{2}$}

\begin{abstract}
Focusing on Unakan, the heroine in male disguise in Bot lakhon nai reung Inao, this paper aims at studying the roles and significance of her character that reflect the outstanding image of a heroine in Thai literature. In the story, Butsaba, the heroine, is disguised by her divine ancestor, Patarakala, as a young man named Unakan. The study reveals that Unakan possesses the characteristics of both hero and heroine. By portraying the roles as parallel to Inao, the hero of the story, Unakan is a great warrior and a dignified hero who has irresistible charm to women. She also searches for the lost lover which is generally the role of a hero. These roles are usually found in many versions of the Panji romances. It reflects
\end{abstract}

\footnotetext{
${ }^{1}$ This paper was presented at the $9^{\text {th }}$ International Conference on Thai Studies (3-6 April 2005) at Northern Illinois University, USA. This paper is part of a Ph.D. dissertation entitled Inao of King Rama II: The Making of the Panji Cycle into a Masterpiece of Thai Court Drama Literature, which was financially supported in part by a Chulalongkorn Graduate Scholarship Commemorating the $72^{\text {nd }}$ Birth Anniversary of H.M. King Rama IX and by the Royal Golden Jubilee Ph.D. Program Scholarship, the Thailand Research Fund. I would like to thank Associate Professor Dr. Cholada Ruengruglikit for her useful guidance and suggestions for this paper.

${ }^{2}$ Ph.D. Candidate, Department of Thai, Faculty of Arts, Chulalongkorn University
}

that the poet kept these outstanding roles of the Panji romances' heroines. Still, Unakan preserves the same characteristics as other heroines in the Thai literary convention. Unakan does not only have perfect beauty and conduct like other Thai ideal women, but she also represents an ideal wife. The character of Unakan has significance to literary aesthetics and values, to the criticism of women's potential, and to Thai literary tradition.

\section{Introduction}

The poets of ancient Thai literature from the Ayutthaya and Bangkok periods usually separated hero roles from those of heroines. The heroes take the role of the active character, while the heroines are passive characters. In the late Ayutthaya period, however, there is at least one female character who does not represent the conventional image of heroine. This character is Unakan, Butsaba in male disguise, from Bot lakhon nai reung Inao. Unakan is different from other Thai heroines because she takes the roles which are generally designed for a hero. Since Unakan is more outstanding than other female characters in Thai literature of that period, this paper attempts to study Unakan's character.

This paper aims at studying Unakan's roles and characteristics from Bot lakhon nai reung Inao as the combination of the conventional Thai hero and heroine. In the paper, I divide the study into three topics:

1) The background of the tales of Inao and the character of Unakan

2) The roles and characteristics of Unakan as a hero and heroine

3) The significances of the combination of hero and heroine characteristics of Unakan 


\section{The Background of The Tales of Inao and Unakan Character}

\section{The Background of The Tales of Inao}

The tales of Inao, or the Panji stories, originated in East Java where Hinduism is the main religion (Robson 1971: 11). It was first found in old Javanese manuscripts. The origin of the tales came from the history of Java around the 11$12^{\text {th }}$ centuries in the period of two great kings, namely King Airalangkha and King Kamesuan, who was King Airalangkha's grandchild. The tales might have been recorded after the period of the two kings which would be around the $13^{\text {th }}$ or $14^{\text {th }}$ century. Inao represents King Kamesuan, and Patarakala, the divine ancestor of the four great kings in the story, represents King Airalangkha. It is believed that some of the plot, e.g. the great battle between Inao and other kingdoms, derived from the biographies of King Airalangkha and King Kamesuan.

The tales of Inao became extensively popular in Java, Borneo, Melayu and Thailand. There are many versions of the Panji stories and it is hard to determine the original one. Each version appears to contain a very similar nucleus of plot but different narrative details, therefore there are different titles bestowed on the various works (Robson 1969: 11).

The tales of Inao were introduced to the Thai court around the $18^{\text {th }}$ century in the reign of King Barommakot in the late Ayutthaya period. A female royal servant, who was Melayu, narrated two versions of the Inao tales, which later became the Thai Inao Yai or Dalang and Inao Lek, to King Barommakot's daughters. Based on the tales they listened to, the two princesses composed the first two Thai versions of Inao in dramatic verse - Klon bot lakhon. The elder princess, Chaofa Kunthon, composed Dalang known as Inao Yai, while the younger princess, Chaofa Mongkut, composed Inao Lek known as Inao.

Later, Inao or the Panji stories became well known. They were popular at the court around the early Rattanakosin period. In the reign of King Rama I, Klon bot lakhon nai reung Inao was recited by the King. After that, in the reign of King Rama II, the King rewrote Klon bot lakhon nai reung Inao from the former texts; Inao Kham Chan and Klon bot lakhon nai reung Inao by King Rama I to be used as the text for Lakhon nai performance. Among the various versions of Inao, Klon bot lakhon nai reung Inao composed by King Rama II is considered a literary masterpiece.

\section{The Background of Unakan's Character}

The main plot of Bot lakhon nai reung Inao concerns the relationship between four kings; Kurepan, Daha, Singhatsari, and Kalang. They are brothers and have a divine ancestor named Patarakala. They get married to members of their own group in order to keep the pure blood of the kingdoms. Inao is the crown prince of Kurepan. Butsaba is the princess of Daha. Their fathers engage them to each other when they are young. Nonetheless, Inao himself does not get a chance to meet his fiancée. When Inao meets another girl, he decides to break off his engagement. Butsaba's father, King Daha, is so angry that he offers to give Butsaba to the first person who asks for her. When Inao meets Butsaba, who is already engaged to 
another man, he falls in love with her. He decides to abduct her and keep her in a beautiful cave. This causes Patarakala to be very angry with him. Patarakala, therefore, blows away the carrier which Butsaba and her followers are riding in order to punish Inao by separating him and Butsaba. Patarakala also casts a spell so that they cannot recognize each other unless the siblings of the four kingdoms meet together. This leads Inao and Butsaba to start their adventure to search for each other. After the long journey, Inao meets Butsaba and returns to his kingdom to succeed his father as the king of Kurepan.

While they are in search of each other, they disguise themselves. Inao disguises himself as a pirate named Panyi and a monk, and Butsaba disguises herself as a young man named Unakan and a nun named Tila-orasa.

The disguise of Butsaba as Unakan starts after the storm, stirred up by Patarakala, blows her away while she is in a carrier in a garden. After that Unakan starts a journey to search for Inao. The disguise leads Unakan to examine and learn about the world in contrast to her former life as Butsaba who is a victim of destiny and always follows the social norm. After Unakan leaves Kalang, one of the four kingdoms in the story, she disguises herself as Aenang (a nun) named Tilaorasa. Therefore, it ends her male disguise as Unakan.

After disguising Butsaba, Patarakala gives her a divine kris, a Malay dagger with scalloped edges, with her name Unakan carved on it.

\begin{tabular}{|c|c|}
\hline $\begin{array}{l}\text { เราจะแต่งแปลงองค์ให้เป็นชาย } \\
\text { พรุ่งนี้ก็จะได้เข้าไป }\end{array}$ & $\begin{array}{l}\text { มิให้คนทั้งหลายสงสัย } \\
\text { สำนักในนครประมอตัน }\end{array}$ \\
\hline & \\
\hline $\begin{array}{l}\text { ว่าแล้วองค์ทา่าวเทเวศร์ } \\
\text { ประทานกริชอันเรืองฤทธิรอน }\end{array}$ & $\begin{array}{l}\text { จึงจำเริญพระเกศสายสมร } \\
\text { จารึกนามกรในกริชนั้น }\end{array}$ \\
\hline อุณากรรณกะหมันวิยาหยา & มิสาเหรนดุหวาเฉิดฉัน \\
\hline เล้วทรงเครื่องอย่างชายพรายพรรณ & เทวัญประสิทธิ์ประสาทพ \\
\hline
\end{tabular}

(Phrabatsomdetphraphutthaloetlanaphalai, 2000: 535)

(She is dressed, by the power of Patarakala, like a young man and is also given a special divine kris with her name Unakan carved on it.)

Patarakala, then, blesses Unakan to achieve great dignity, success, victory and to be the beloved one of everybody as cited below.

$\begin{array}{ll}\text { แม้นเจ้าจะไปแห่งใด } & \text { ให้คนมีใจสโมสร } \\ \text { ปรากฏยศเกียรติทุกนคร } & \text { จงขจรเลื่องชื่อลือชา } \\ \text { จะประสงค์สิ่งใดให้สำเร็จ } & \text { สมเสร็จดังใจปรารถนา } \\ \text { บรรดาแว่นแคว้นแดนชวา } & \text { อย่ารู้อัปราชัยใคร }\end{array}$

(Phrabatsomdetphraphutthaloetlanaphalai 2000: 535-536)

(Patarakala blesses Unakan that wherever she journeys, everyone will treat her with kindness. Unakan will achieve dignity, be popular, be successful in everything, and be able to win a battle over other kingdoms.)

While blessing Unakan, Patarakala casts a spell on her and Inao so that they will not recognize each other unless the siblings of the four kingdoms: Inao, Butsaba, Siyatra, and Wiyada, meet together. 


$\begin{array}{ll}\text { ถึงจะพบอิเหน ากุเรปัน } & \text { ให้แคลงกันฟั่นเฟือนสงสัย } \\ \text { ต่อสี่พี่น้องร่วมเวียงชัย } & \text { จึงให้รู้จักศักดิกัน } \\ \text { ใครใครนอกนั้นทั้งปวง } & \text { อย่าให้ล่วงแจ้งการหลานขวัญ } \\ \text { ครั้นประสิทธิ์พรแล้วเทวัญ } & \text { คืนยังกระยาหงันชั้นฟ้า }\end{array}$

(Phrabatsomdetphraphutthaloetlanaphalai, 2000: 535-536)

Cholada Ruengruglikit (2003) analyzes that the blessing and the spell of Patarakala can be considered as the short biography of Unakan called 'Sutsathani' because the blessing and the spell portray well how the life of Butsaba disguised as Unakan will be until the disguise ends (2003: 213-216). The biography might signify the starting of Butsaba's new life as a man. The biography thus reflects the significance of Unakan as parallel to Inao, who has his own 'Sutsathani' or biography as well.

It is interesting that while Unakan is disguised as a man, the heroine in other Thai versions of Inao such as Dalang or Inao yai and Ari-nakkhara version is transformed by Patarakala.

In Dalang, after Patarakala takes Butsabakalo from Daha into a forest, he transforms her into a man, gives her a divine kris (a Malay dagger) and names her Misapramangkuning (มิสาประหมังกุหนิง).

\begin{tabular}{|c|c|}
\hline อัยกาจะจำแลงแปลงกาย & ให้เป็นชายเยาวยอดเรืองศรี \\
\hline ต่อพบคุ่ตุนาหงันของเทวี & ที่สมศรีสุริย์วงศ์อันเดียวกัน \\
\hline ถ้าได้แจ้งแห่งศักดิ์ทั้งสองรา & จึ่งกลับกลายกายาดั่งสาปสัน \\
\hline คืนเป็นสตรีดั่งเก่านั้น & หลานขวัญจงแจ้งอย่าแคลงใจ \\
\hline เมื่อนั้น & สุรารักษ์ศักดิ์ศรีที่สูงส่ง \\
\hline จึงร่ายเวทย์วิเศษอันยืนยง & เป่าลงที่องค์นัดดา \\
\hline ครั้นครบคำรบเจ็ดคาบ & ประสาทพรให้ประสิทธิ์ดั่งปรารถนา \\
\hline ที่ทรวงเต่งเคร่งครัดเต็มอุรา & หายไปกับตาทันที \\
\hline แล้วจำเริญเกศเกล้าอย่างบุรุษ & ทรงโฉมบริสุทธิ์มีศรี \\
\hline
\end{tabular}

(Phrabatsomdetphraphutthayotfachulalok, vol. I 1971: 395)

(Patarakala, the divine ancestor, transforms Butsabakalo into a man both in appearance and figure and causes her breasts to disappear. $\mathrm{He}$ also casts a spell that she will have her female figure back if she and Inao recognize each other.)

In Ari-nakkhara, after the storm, by the power of Patarakala, blows Chindarakirankalo and her followers away from Daha into a forest, Patarakala transforms her into a man similarly to Butsabakalo in Dalang and names her Ratukalanasattravirat (ระตูกลานาสัตราวิราช).

'แล้วมีสุรเสียงว่า นางกาโละจินดะหรากิรันเจ้าจงเป็นเหมือนชาย ให้มีรูปร่างสูงใหญ่งดงาม บรรดาศัตรูที่คิดร้ายก์ให้พ่ายแพ้ ไม่ให้ ต่อสู้ได้ทั้งสิ้น เว้นไว้แต่ระเด่นอิเหนาอังกุเรปัน ซึ่งเป็นคู่ตุนาหงัน มาแต่เดิม ได้ประทานเวทมนตร์เครื่องอาวุธและสัตว์พาหนะแก่ นางพร้อมเสร็จ โดยอำนาจของปะตาระกาหลา นางจินดะหรากิ รันกาโละ กับนางมะดูสรีพี่เลี้ยง ก็กลับกลายเป็นชายขึ้นในทันใด นั้นเอง แล้วให้ทรงพระนามว่า เจ้าระตูกลานาสัตราวิราช'

(Khunnikonkanprakit, 2520: 152)

(Patarakala transforms Chindarakirankalo into a smart and strong man. He blesses her to have victory over all her enemies except Inao. He also gives Chindarakirankalo a divine kris and vehicle and names her Ratukalanasatravirat.)

\section{The Roles and Characteristics of Unakan as a Hero and Heroine}

In Thai literary convention, heroines have their 'roles' -- roles which are generally separated from those of the heroes. The heroines are always protected by the heroes. If they are abducted by the villain or separated from their husband, they have to wait for their husband's help. Moreover, 
they are always faithful to their husbands even after their separation. The heroes always take the role of searching for the lost lover and warriors during the adventure.

There are a few unconventional heroines in Thai literature, for example, the heroine who has more than one lover or husband such as Mora in Chanthakorop, and the heroine who takes the role of hero.

Generally, there are three techniques that Thai poets use to create the unconventional heroines who represent the hero image. First, the poet might transform the heroine into a man and then let the heroine play the hero role, as for example, Misapramangkuning from Dalang. The transformed heroines usually get magic power or a magic weapon from the gods and display their power as the hero. Second, the poet might disguise the heroine as a man, as for example, Unakan. The disguised heroines may get or not get any magic power and weapon. The disguised heroines sometimes act like male characters and sometimes like female characters. Finally, the poet might let the heroine take the hero roles without disguise and transformation, for example, Laweng from Phra Aphaimani.

Regarding the role and characteristics, Unakan could be considered the unconventional Thai heroine who combines the hero roles and characteristics with those of the heroine in male disguise.

\section{The Roles and Characteristics of Unakan as a Hero}

Unakan' $s$ hero roles and characteristics are so outstanding that she can be considered as one of the heroes of the story. It is found that Unakan exhibits three images of a hero which are: a hero who has an irresitable charm to women, a wanderer, and a great warrior.

\section{1) The hero who has an irresistible charm to women}

Charming is one of the characteristics of a Thai hero. During the adventure, Unakan ${ }^{3}$ uses his mighty power to gain numerous women as his consorts similar to Panyi (Inao). The scene showing Unakan's image as the hero who is seen as irresistible to women is portrayed when he is in Kalang. Malara, the daughter of a court chief, falls in love with him.

\begin{tabular}{|c|c|}
\hline แต่ได้เห็นองค์อุณากรรณ & ให้รักใคร่ผูกพันเสนหา \\
\hline พิศวงด้วยทรงโสภา & องจิตติดตาอยู่ไม่วาย \\
\hline อกเอ๋ยจะแนะ & จะได้สบสมอารมณ์หมาย \\
\hline คิดคิดขึ้นม & นหญิงจะชวนชายก็ใช่ที่ \\
\hline
\end{tabular}

(Phrabatsomdetphraphutthaloetlanaphalai 2000: 616)

(Upon seeing Unakan, Malara falls in love with him. She is mad for his good looks. She is embarrassed about falling in love with him because she cannot ask for his love.)

Similarly to Unakan, the romantic scene happens to Panyi as well. When he is riding into Malaka, Wanyiwa, a daughter of a court chief, loves him at first sight. Upon first sight, Malara gives Unakan some beautiful flowers signifying her love for him. Unakan knows Malara's meaning and gives a response to Malara. This is said in the text below.

\footnotetext{
${ }^{3}$ On this topic I would like to use 'He', 'him', and 'his' to represent Unakan because I am trying to explain the male image of Unakan.
} 
$\begin{array}{ll}\text { จึงใส่กลแย้มยิ้มพริ้มเพรา } & \text { หยิบเอาดอกไม้ในห่อผ้า } \\ \text { ดมพลางทางดูให้สบตา } & \text { ทำมารยาเหมือนจะใคร่เป็นไมตรี }\end{array}$

(Phrabatsomdetphraphutthaloetlanaphalai 2000: 618)

(Unakan pretends to smile and be pleased with Malara's flowers. He softly smells them while lifting his eyes up to Malara's eyes.)

Later on Malara comes to see Unakan at his palace. Unakan deceives Malara. He says he cannot sleep with any woman for three years because he has promised to a god. Malara feels upset to hear that. However she swears to be faithful to Unakan. Unakan gives Malara his Sabo (a shawl) and a ring in order to please her.

The circumstance in which Unakan talks to Raden Kusuma, one of his captives, also represents the image of the hero who treats a woman charmingly. By his companions' suggestion, Unakan has to ask Raden Kusuma to sleep with him to avoid any suspicion. Unakan has to deceive the princess that he cannot make love with any woman for three years as he has vowed to a god. As Unakan learns from the way Inao treated him when he is Butsaba, Unakan knows how to treat a woman and how to impress a woman. As Unakan says to Raden Kusuma, the princess of Lasam, whom he asks to sleep with,

\begin{tabular}{|c|c|}
\hline กรประคองต้ององค์นงลักษณ์ & เลิกสไบจากพักตร์แล้วรับขวัญ \\
\hline ไลอบวนิดาลาวัณย์ & อย่าทรงกันแสงเลยนะทรามวัย \\
\hline จงหักห้ามความโศกเสียบ้าง & คิดคะนึงถึงทางพิสมัย \\
\hline ตุรงค์ขององค์อรไท & ท่านไม่มีจิตคิดเมตตา \\
\hline ให้เจ้ามาเป็นเชลยพี่ & เมื่อกระนี้ยังแค่นกันแสงหา \\
\hline เจริงฤาจะให้เจ้าไกลมา & จะต่อฤทธิ์พี่กว่าจะสุดรู้ \\
\hline ตรแม้นพ่ายแพ้ก็จำเป็น & จึงจะเห็นประจักษ์ว่ารักอยู่ \\
\hline
\end{tabular}

\begin{tabular}{|c|c|}
\hline ส่วนท่านทำได้ไม่เอ็นดู & โฉมตรูจะร่ำรักไย \\
\hline มาร่วมรักกับพี่ดีกว่า & จะทำเช่นบิดาเจ้าหาไม่ \\
\hline จะพันตูสู้ตายมิให้ใคร & อย่าร้องไห้ไปเลยนะเทวี \\
\hline
\end{tabular}

(Phrabatsomdetphraphutthaloetlanaphalai 2000: 593)

(Raden Kusuma is crying because she misses her father, King Lasam. Unakan softly enfolds her and tries to relieve Raden Kusuma's sadness by soothing her that he loves her more than her father.)

The image of Unakan as a charming hero can be compared to Panyi. During the search, Panyi gains numerous women from his great power to be his captives as well. Raden Kanchana, the princess of Wangkan, impresses him very much because she looks like Butsaba. Panyi, therefore, asks Raden Kanchana, the princess of Wangkan, to sleep with him. The way Panyi treats Raden Kanchana is similar to the way Unakan treats Raden Kusuma.

\begin{tabular}{|c|c|}
\hline Unakan & Inao \\
\hline เมื่อนั้น & เมื่อนั้น \\
\hline อุณากรรณกล่าวคำอ่อนหวาน & ปันหยียิ่งมีเสนหา \\
\hline โฉมเฉลาเยาวยอดยุพาพาล & ยุดมือไว้แล้วจึงว่ามา \\
\hline พี่แสนรักหักหาญมาหาน้อง & อย่าวันทาพี่เลยนะเทวี \\
\hline ควรหรือสาวน้อยถอยหนี & ตัวพี่นี้ชาติชาวดง \\
\hline ทำทีระคางหมางหมอง & ไม่ควรนวลอนงค์จะไหว้พี่ \\
\hline โลมลูบปฤษฎางค์พลางประคอง & ตัวเจ้าเป็นราชบุตรี \\
\hline นวลละอองจงฟังวาจา & มีกรรมจำได้แก่ชาวไพร \\
\hline พี่ก็ขังไม่เคยมีคู่ & ถึงพี่นี้ต่ำช้าบรรดาศักดิ์ \\
\hline ให้อดสูแก่ใจหนักหนา & แต่ใจใฝ่รักที่ศักดิ์ใหญ่ \\
\hline รักเจ้าเท่าเทียมชีวา & วาสนาเคยสร้างกับนางไว้ \\
\hline อนิจจาไม่คิดปรานี & ด้วยจะได้พึ่งเดชกษัตรา \\
\hline (Phrabatsomdetphrap & ว่าพลางแอบอิงพิงพาด \\
\hline hutthaloetlanaphalai & สุดสวาทอย่างอนจงผ่อนหา \\
\hline 2000: 594) & กรกระหวัดรัดรึงตรึงตรา \\
\hline (Unakan says sweetly & แก้วตาของพี่จงปรานี \\
\hline to Raden Kusuma & (Phrabatsomdetphrap \\
\hline
\end{tabular}




\begin{tabular}{|c|c|}
\hline Unakan & Inao \\
\hline $\begin{array}{l}\text { that he really loves } \\
\text { her, so Raden } \\
\text { Kusuma should not } \\
\text { feel afraid of him. } \\
\text { Unakan softly } \\
\text { touches Raden } \\
\text { Kusuma's shoulder } \\
\text { and enfolds her. } \\
\text { Unakan, then, says }\end{array}$ & $\begin{array}{l}\text { Hutthaloetlanaphal } \\
\text { ai } \\
\text { 2000: 560) } \\
\text { (Panyi touches } \\
\text { Raden Kanchana's } \\
\text { hands in order to } \\
\text { restrain her from } \\
\text { paying respect to } \\
\text { him. Panyi gives } \\
\text { her a reason that }\end{array}$ \\
\hline $\begin{array}{l}\text { to her that he has } \\
\text { never loved any } \\
\text { woman unitl he } \\
\text { meets her.He really } \\
\text { loves her as much } \\
\text { as his life. }\end{array}$ & $\begin{array}{l}\text { he is only a } \\
\text { pirate, so she } \\
\text { has not to } \\
\text { respect him. } \\
\text { Panyi softly } \\
\text { holds her in his } \\
\text { arms with love.) }\end{array}$ \\
\hline
\end{tabular}

Unakan, therefore, has to take part in many love affairs with women. This gives him a good chance to learn a man' $s$ life and also represents one of the characteristics of a hero in Thai literature.

\section{2) The Wanderer}

One of the images of a great hero is the wanderer. To be a great hero, one has to ride out to take a journey and confront the unknown in order to mark the beginning of life lived at a new level and find himself.(Pearson 1998: 65) The role is generally designed for traditional Thai heroes who take the journey to search for their lost lovers as we can find in many Thai tales known as Nitan Chak Chak Wong Wong.

Similarly to most great heroes, Unakan takes the adventure to search for Inao, her husband. In addition, Unakan's quest for Inao paralells Inao who disguises himself as a pirate to search for Butsaba as well. It is an interesting plot in Thai literature representing the adventures of a woman who searches for her husband since Thai heroines generally wait for their husbands or heroes to search for them.

Unakan's great journey begins after Patarakala disguises her in the forest of Pramotan. As Unakan says to his two companions,

$\begin{array}{ll}\text { จึงปรึกษาพี่เลี้ยงทั้งสองศรี } & \text { เราจะอยู่ที่นี่ไม่ได้ } \\ \text { จำจะเที่ยวซอกซอนสัญจรไป } & \text { จะได้พบประเทศธานี }\end{array}$

(Phrabatsomdetphraphutthaloetlanaphalai 2000: 536)

(Unakan tells his companions that all of them have to take a journey in order to find some kingdom to stay in.)

The journey leads Unakan to experience a new world he has never met before. As Unakan says,

อกเอ๋ยไม่เคยเดินไพร เคยสำราญแต่ในพระบุรี

(Phrabatsomdetphraphutthaloetlanaphalai 2000: 536)

(Unakan has never travelled in a forest.Unakan is used to living happily in the palace.)

While taking a journey in the forest, Unakan meets King Pramotan and his followers. Unakan extremely impresses him, so he asks Unakan to be his adopted son and the crown prince. Unakan, however, stays in the kingdom briefly because he would like to search for Inao again. Unakan gives King Pramotan his reason for leaving the kingdom that he would like to find his wife, which is also an aspect of the conventional Thai hero. At the same time Patarakala appears to point out to Unakan that at that time Inao is staying in the east. Unakan thus starts 
his adventure of searching for Inao again. He says in the text:

$\begin{array}{ll}\text { เที่ยวเตร่เร่ตามพระเชษฐา } & \text { ไม่รู้ว่าจะไปหนไหน } \\ \text { แรมรอนนอนทางมากลางไพร ก็ได้หลายทิวาราตรี }\end{array}$

(Phrabatsomdetphraphutthaloetlanaphalai 2000: 591)

(Unakan takes a journey to search for Inao and has to stay in a forest for many days. He does not know exactly where he should go.)

The journey gives Unakan (and also Panyi) a chance to present his prowess and establish his power as I will discuss in the next section.

\section{3) The Warrior}

Another important archetype of a hero seen in Unakan is a great warrior. This image might connect to the meaning of his name, Unakan. The word Unakan might come from the Javanese word Undakan (Robson 1969: 19) or Oendakan (Plaek Sinlapakamphiset 1976: 193) which means a horse or a knight. The use of animalnames is typical of Javanese Panji literature and Middle Javanese literature in general (Robson 1969: 19). The meaning of this name might signify the ability and the great duty of the owner.

Unakan plays an important role as the outstanding military leader who can subdue all his foes similar to Inao or Panyi, during his adventure in the world of conquest.

Unakan has learned military strategy at Pramoton where Unakan lived as the adopted son of the king. This is the first step of Unakan's becoming a warrior.
แล้วให้เรียนรู้การณรงค์ สำหรับองค์พระโอรสา

(Phrabatsomdetphraphutthaloetlanaphalai

2000: 543)

(King Pramotan encourages Unakan to learn battle strategy.)

Unakan is extolled by every kingdom even Panyi as a great warrior. As Panyi says about Unakan,

$$
\begin{array}{ll}
\text { เขาลือว่าอุณากรรณนี้ } & \text { ฤทธีสามารถอาจหาญ } \\
\text { ระตู้ใดไม่ต้านทาน } & \text { เที่ยวรบรุกรานทุกธานี }
\end{array}
$$

(Phrabatsomdetphraphutthaloetlanaphalai 2000: 597)

(Panyi has heard that Unakan is a great warrior who is able to defeat every kingdom.)

By his great power, Unakan gains numerous captives and many kingdoms surrender to him. His mighty authority can be compared to Panyi, as the table shows:

\begin{tabular}{|l|l|}
\hline \multicolumn{1}{|c|}{ Unakan } & \multicolumn{1}{c|}{ Inao } \\
\hline \multicolumn{1}{|c|}{ มาจะกล่าวบทไป } & \multicolumn{1}{c|}{ เมื่อนั้น } \\
ถึงท้าวปะตาหรำเรืองศรี & ระตูอกสั่นขวัญหาย \\
กับทั้งระตูทุกบุรี & ตกใจระรัวกลัวตาย \\
บรรดาที่อยู่ใกล้หนทางไป & แพ้พ่ายไม่รอต่อฤทธิ์ \\
แเจ้วว่ามิสาอุณากรรณ & บรรดาธานีทุกประเทศ \\
ยกพวกพลขันธ์ทัพใหญ่ & ก็เกรงเดชเดชาอาญาสิทธิ์ \\
มาหักหาญรานรุกชิงชัย & ระตูต่างองค์ทรงคิด \\
ต่างตระหนกตกใจเป็นพ้นคิด & จะผูกพันเป็นมิตรไมตรี \\
ด้วยเดชปะตาระกาหลา & ให้แต่งเครื่องบรรณาการ \\
ลงมาบันดาลดลจิต & มาขอขึ้นแก่มิสาระปันหยี \\
ทุกระตู่อท้อไม่ต่อฤทธิ์ & ถวายทั่งโอรสแลบุตรี \\
นึกกจะใคร่เป็นมิตรไมตรี & สั่งให้เสนีนำไป \\
จึงจัดแจงแต่งเครื่องบรรณาการ & (phrabatsomdet \\
ทั้งธิดากุมารมีศรี & phraphutthaloetl \\
ต่างองค์ทรงสั่งเสนี & anaphalai 2000: \\
ให้คุมของทั้งนี้ไคลคลา & 553-554) \\
\hline
\end{tabular}




\begin{tabular}{|c|c|}
\hline $\begin{array}{l}\text { ไปขอออกแก่องค์อุณากรรณ } \\
\text { ผูกพันไมตรีเสีดคีกว่า } \\
\text { อย่าให้ปัจจามิตรติดพารา } \\
\text { ไพร่ฟ้าประชากรจะร้อนรน } \\
\text { (phrabatsomdet } \\
\text { phraphutthaloetl } \\
\text { anaphalai 2000: } 588 \text { ) } \\
\text { (When numerous kings } \\
\text { have heard that Unakan } \\
\text { takes his army to battle } \\
\text { against them, they } \\
\text { become frightened. } \\
\text { By the power of } \\
\text { Patarakala, all of the } \\
\text { kings give } \\
\text { Unakan their tributes } \\
\text { and their } \\
\text { sons or daughters } \\
\text { in order to pay } \\
\text { respect to Unakan }\end{array}$ & $\begin{array}{l}\text { Numerous kings } \\
\text { feel very frightened } \\
\text { of Panyi, so they } \\
\text { give Panyi their } \\
\text { tributes and their } \\
\text { sons or daughters } \\
\text { in order to pay } \\
\text { respect to him.) }\end{array}$ \\
\hline
\end{tabular}

The great war that leads Unakan to prove his potential as a great warrior is the war between Kalang and Chamara. Since King Kalang refuses to marry his daughter, Raden Sakaraneungrat, to King Chamara, the war happens. King Chamara takes his army with his elder brother, King Kapalan to fight against King Kalang. This war enables Unakan to play the important role as a warrior parallel to Panyi. Panyi asks Unakan to fight against King Chamara, while he fights with King Kapalan. The situation signifies the equal importance of the two heroes, Unakan and Panyi, since their enemies, King Chamara and King Kapalan, have the same great power. As the poem describes,

$$
\text { เสวยไอศวรรยามาช้านาน ทั้งสองศฤงคารเสมอกัน }
$$

(Phrabatsomdetphraphutthaloetlanaphalai 2000: 659)
(The two kings, King Chamara and King Kapalan, have the same wealth and power.)

The outstanding warrior of the war is Unakan. Panyi asks her to fight against King Chamara first while he fights after that. The war seems to be a competition between Unakan and Panyi.

Before going to battle, Unakan feels very worried and afraid because Unakan has never gone into battle. It is reasonable for a woman who has never experienced any fighting. Patarakala, therefore, comes from heaven to soothe Unakan. As the poem says,

$$
\begin{array}{ll}
\text { แจ้งว่าจะออกรบไพรี } & \text { ประกวดกับปันหยีเป็นการใหญ่ } \\
\begin{array}{ll}
\text { เป็นหญิงไม่เคยชิงชัย } & \text { คงประหวั่นพรั่นใจเป็นพ้นคิด } \\
\text { จำกูจะลงไปโลมเล้า } & \text { ให้บรรเทารันทดสลดจิต }
\end{array}
\end{array}
$$

(Phrabatsomdetphraphutthaloetlanaphalai 2000: 675)

(Patarakala knows how worried Unakan is about the battle which would be compared

\begin{tabular}{|c|c|}
\hline เจ้าอย่าหวาดหวั่นพรั่นจิต & จะพ่ายแพ้ปัจจามิตรนั้นหาไม่ \\
\hline อัยกาจะช่วยอวยชัย & บันดาลให้ไพรีอัปรา \\
\hline $\begin{array}{l}\text { งแข็งใจทำให้เหมือนชาย } \\
\text { ประสาทพรสอนสั่งพระนัดดา }\end{array}$ & $\begin{array}{l}\text { อย่าให้อายปันหยีสุกาหรา } \\
\text { แล้วคืนยังชั้นฟ้าสุราลัย }\end{array}$ \\
\hline
\end{tabular}
with Panyi, so he comes to soothe her.)

When Patarakala appears to Unakan, he tells him:

(Phrabatsomdetphraphutthaloetlanaphalai 2000: 675)

(Patarakala soothes away Unakan's anxiety. He blesses Unakan to have a victory over the enemies and reminds Unakan to pretend to be a man as well.)

After meeting Patarakala, Unakan feels better. As the poem says: 


$$
\begin{array}{ll}
\text { เมื่อนั้น } & \text { อุณากรรณรัศมีศรีใส } \\
\text { ทั้งสองพี่เลี้ยงทรามวัย } & \text { ค่อยสบายคลายใจที่จาบัลย์ } \\
\text { ต่างคนชื่นชมภิรมย์ชิต } & \text { ไม่คิดเกรงขามคร้ามครั่น }
\end{array}
$$

(Phrabatsomdetphraphutthaloetlanaphalai 2000: 676)

(Unakan and her companions feel better. They are happy and gain courage.)

Unakan has to fight with Ratu Chamara. Before the battle starts, Unakan feels anxious again, so he prays to Patarakala. Patarakala, therefore, gives his sign to Unakan in the battle field. As the poem describes:

$$
\begin{aligned}
& \text { เห็นระตูบุกบั่นกระชั้นมา ตกประหม่าหน้าซีดลงทันใด } \\
& \text { ด้วยไม่เคยรณรงค์สงคราม ให้เกรงขามคร้ามครั่นหวั่นไหว } \\
& \text { เหลือบดูปันหขีเป็นทีไป หวังจะให้มาเรียงเคียงพักตรา } \\
& \text { ครั้นเห็นไม่หนุนก็น้อขจิต จึงคิดถึงปะตาระกาหลา } \\
& \text { ขอเชิญพระองค์ลงมา ช่วยข้าครั้งนี้ให้มีชัย }
\end{aligned}
$$

(Phrabatsomdetphraphutthaloetlanaphalai 2000: 723)

(When Unakan sees Ratu Chamara coming to him, Unakan is suddenly frightened. Unakan hopes Panyi (Inao) will help him but Panyi does not, so Unakan prays to Patarakala.)

Patarakala, then, appears on the battlefield only to Unakan. Patarakala soothes him again.

$$
\begin{array}{ll}
\text { แล้วบัญชาตรัสแก่นัดดา } & \text { เจ้าอย่าตกใจไหวหวั่น } \\
\text { อันระตูจะมาหรานั้น } & \text { จะมอดม้วยชีวันเป็นมั่นคง }
\end{array}
$$

(Phrabatsomdetphraphutthaloetlanaphalai 2000: 686)

(Patarakala soothes Unakan's anxiety away and blesses that he will defeat Ratu Chamara.)
After seeing Patarakala and hearing his blessing, Unakan regains the courage to fight.

$$
\begin{array}{cl}
\text { เมื่อนั้น } & \text { อุณากรรณชื่นชมสมประสงค์ } \\
\text { มิได้ย่อท้อต่อณรงค์ } & \text { หยุดขืนม้าทรงคอยที }
\end{array}
$$

(Phrabatsomdetphraphutthaloetlanaphalai 2000: 687)

(Unakan is happy and regains the courage for the battle.)

Patarakala can symbolize his inner warrior spirit and his own ability. The effect of the magic is not to change Unakan's ability, but rather to cause the true nature to be revealed. Then, Unakan bravely kills Ratu Chamara. As the poem describes:

$\begin{array}{ll}\text { ชักอาชาหันเหียนเวียนวง } & \text { พระหัตถ์ทรงหอกซัดเงื้อง่า } \\ \text { ได้ทีพุ่งพวยตรวยตรงมา } & \text { ต้องระตูตกม้าม้วยชีวี }\end{array}$

(Phrabatsomdetphraphutthaloetlanaphalai 2000: 690)

(Unakan and Ratu Chamara are fighting against each other on horseback and Unakan kills him.)

In this scene, we clearly see the inner conflict of Unakan between fear and courage during the battle. When Unakan triumphs over fear, he gains the courage to fight. The victory over Ratu Chamara can signify the victory of Unakan's courage over his fear. It really proves Unakan's ability and spirit as a military woman.

While Unakan tries to use the ability that he learns at Pramotan to fight, Misapramangkuning in Dalang defeats his enemies by the powerful kris or dagger and the magic of Patarakala as cited below: 


\begin{tabular}{|c|c|}
\hline บรรดายุทธนาในธาตรี & ศิลปศาสตร์เหล่านี้จงเจนใจ \\
\hline หลานรักจงต่อรณรงค์ & ถ้าแทงต้ององค์อย่าหวาดไหว \\
\hline แข็งดั่งศิลาไป & ดุจแทงเนินไศลบรรพตา \\
\hline ก & ชั0าค \\
\hline
\end{tabular}

(Phrabatsomdetphraphutthayotfachulalok, Vol. I 1971: 396)

(Patarakala blesses Misapramangkuning that he will be strong like a mountain and a stone that enemies cannot stab him, while he can stab them easily.)

When Misapramangkuning fights against Ratu Pratahon's brothers, they cannot stab and injure him at all because of the divine kris and magic of Patarakala.

\begin{tabular}{ll}
\multicolumn{1}{c|}{ เมื่อนั้น } & มิสาประหมังกุหนิงไม่หวั่นไหว \\
อาวุธะะมาสักเท่าใด & มิได้ต้องสกนธ์กาย \\
พระปัดด้วยกริชเทวัญ & อาวุธหักสะบั้นฉิบหาย \\
พระกุมกริชยุรยาตรนาดกราย & ปีนป่ายขึ้นงาไอยา
\end{tabular}

(Phrabatsomdetphraphutthayotfachulalok 1971: 410)

(No weapon can harm Misapramangkuning because of the powerful kris)

The victory of Misapramangkuning, therefore, comes from the power of Patarakala, while the victory of Unakan comes from his potential. Compared to Misapramangkuning who is transformed, Unakan, though disguised, is more reasonable and convincing.

The three roles above form and portray well the heroic image of Unakan. The image is not found only in Klon bot lakhon nai reung Inao, the Thai Panji version, but also in many versions of the Javanese and Melayu Panji romances, for example, Djajakusuma, Hikayat Kuda Semirang, Pandji Kuda-Narawangsa, Phongsawadan Inao Chabap Ari-nakkhara, Hikayat Panji
Semirang. The heroines in the versions of Panji romance mentioned above are transformed or disguised as men and take adventures in order to search for the hero and also take the role of the warrior similarly to Unakan. It can be considered that Klon bot lakhon nai reung Inao preserves the outstanding aspect of the heroine of the Panji romances. However, in the Thai version, Unakan also represents the characteristics of conventional Thai heroines, which makes the character reasonable and different from the heroines in other versions of Panji.

\section{The Roles and Characteristics of Unakan as a Heroine}

While playing the significant roles as the hero, Unakan preserves the same characteristics as other heroines in Thai literary convention as well. Unakan does not only have perfect beauty and conduct like other Thai ideal women, but she also represents an ideal wife who remains faithful to her husband after their separation.

A heroine in Thai literary convention always has a perfect beauty which signifies her virtue and high status. The poet describes Unakan's ideal beauty which is a sign of her high status as a lineage of god or 'Wong deva'.

While Panyi is riding a horse into Kalang, people come to see him and compare his perfect beauty to Unakan's. The description reveals the tradition of praising the beauty of the hero and heroine in Thai literature which usually compares the beauty of the hero to that of the sun and the beauty of the heroine to that of the moon. As they say: 


อันว่าโฉมอุณากรรณกับปันหญี
อุณากรรณนั้นดีเป็นทีนาง
แต่ขี่ม้าดูหน้าเห็นชายก้ม
งามเหมือนพระจันทรัอันอำไพ
อันปันหยีนี้งามมีสง่า
ขึงขังมั่นคงเป็นทรงชาย
งามเหมือนดังองค์พระสุริยา

งามดีแต่ละกลคนละอย่าง

รูปร่างกิริยาละม่อมละไม

จะสมเป็นบุรุษนั้นหาไม่

ดูได้ทั่วทั้งหญิงชาย

ท่วงทีขี่ม้าก์เฉิดฉาย

หูตาสอดส่ายเป็นพ้นไป

ข้าอดตาไม่กล้าแลดูได้

(Phrabatsomdetphraphutthaloetlanaphalai 2000: 634)

(Unakan is as beautiful as the moon while Panyi is as handsome as the sun.)

Moreover, Unakan has feminine conduct like other Thai heroines. For example, she feels shy when she is stared at by a man especially Panyi.

She first meets Panyi who disguises himself as a monk in a temple on a mountain while she is taking a journey to search for Inao. When Unakan is stared at by Panyi who wonders whether she is a man or not, she feels shy.

$$
\begin{array}{ll}
\text { เหลือบไปเห็นให้พักตรากัน } & \text { แข้มยิ้มคมสันอยู่ในหน้า } \\
\text { อายดังจะละลายกายา } & \text { จึงว่าเข็นแล้วจะลาไป }
\end{array}
$$

(Phrabatsomdetphraphutthaloetlanaphalai 2000: 604)

(Unakan feels very shy of Panyi as if she will be melted by his eyes.)

The next feminine behavior of Unakan is to feel frightened of blood. When she sees King Chamara' s blood after defeating him, she suddenly feels frightened and seems to faint. It is reasonable for a woman who has never experienced the battlefield.

$$
\begin{aligned}
& \text { อุณากรรณครั้นเห็นโลหิต } \text { ให้คิดตระหนกตกประหม่า } \\
& \text { เมาเลือดผาดเผือดพักตรา }
\end{aligned}
$$

(Phrabatsomdetphraphutthaloetlanaphalai

2000: 690)

(When Unakan sees King Chamara' s blood, she is frightened and her face becomes pale because she has never killed anyone.)

Unakan, in addition, is the ideal wife similar to other heroines in Thai literary convention. The aim of her journey is to search for Inao, her husband. It reveals how she loves him and how she remains

\begin{tabular}{|c|c|}
\hline สายหยุดยมโดยลำดวนดง & ลมส่งหอมซาบนาสา \\
\hline เหมือนกลิ่นซ่าโบะพระพี่ยา & ซึ่งเปลี่ยนไว้เมื่อลาไปธานี \\
\hline นถอนใจอาลัยห & กันแสงทรงโศกเศร้าหมองศรี \\
\hline รีบรถคชพลพาชี & จรลีไปตามรคา \\
\hline
\end{tabular}
faithful to him even after their separation. She always recalls Inao and expresses how much she loves him. As she says:

(Phrabatsomdetphraphutthaloetlanaphalai 2000: 586)

(The fragrance of flowers reminds her of the smell of Inao's Sabo (shawl). She becomes sad and starts crying.)

It can be concluded that Unakan is an active character who represents both masculinity and femininity.

\section{The Combination of Hero and Heroine Characteristics of Unakan: The Significance}

From the study, it can be concluded that the character of Unakan has three significances, which are: the significance to literary aesthetics and values, the significance as the criticism of women' $\mathrm{s}$ potential, and the significance to literary tradition. 


\section{The Significance to Literary Aesthetics}

The character of Unakan creates the literary aesthetics of the story. The combination of hero and heroine characteristics makes the plot reasonable and impressive for Thai people. The way Unakan tries to hide her femininity and reveal masculinity to the society might attract the audience.

In addition, the mixture of masculinity and femininity of Unakan that causes Inao to be doubtful whether Unakan is a man or a woman relates to the sub-theme of the story which comes from the spell of Patarakala. Patarakala casts the spell on Inao and Butsaba that they will not recognize each other unless the siblings of the four kingdoms meet together. The story thus has a sub-theme about the search for the lost lover, and the doubt and recognition of each other. If Unakan is transformed and clearly maintains masculine characteristics without preserving her feminine characteristics, it is not reasonable to cause doubt in Inao and the sub-theme will not be clear as well.

\section{The Significance as a Criticism of Women's Potential}

The life of Unakan, who combines the images of the Thai hero and heroine, might be considered as a criticism of women's potential.

The disguise and the adventure give Unakan the opportuniy to demonstrate her ability. She takes part in the adventure and the battle as a warrior. Although Unakan feels nervous or worried in some conditions such as in the battle, the reason is that she has never experienced them, not because she is a woman. Since she proves her heroism by fighting against her nature, she is presented not as sufferer but as saviour. The adventure thus reflects that femininity is not an obstacle to taking male roles or duties. It is interesting that the first poet who composed Klon bot lakhon nai reung Inao was a woman, Chaofa Mongkut. She composed Klon bot lakhon nai reung Inao after she listened to a Panji tale from a female royal servant who was Melayu. One of the reasons why the potential of the heroine is well portrayed might be that one of the poets of the story was a woman.

However, under the social constraints, it seems that a woman, only disguised as a man, can prove her potential and intelligence. The disguise thus could be considered as a literary technique to reveal a woman's ability.

\section{The Significance to Literary Tradition}

The character of Unakan signifies a new aspect of heroines in Thai literary tradition that a heroine does not only play the limited roles in the family as a mother or a perfect wife, but she also performs the great role of an intelligent leader and a warrior of a state.

Moreover, the character of Unakan might influence some female characters in later Thai literary works. In Phra Aphaimani, the masterpiece of Sunthonphu, Laweng and Suwannamali, the heroines of the story, reveal their intelligence and abilities by acting as state leaders and warriors similar to Unakan but they do not disguise themselves. These characters can be considered as the lineage and the development of Unakan's characteristics. 
In modern literature, there is at least one work interpreting the character of Unakan. This work is Butsaba-Unakan, a modern Thai drama, by Matthani Mochadara Rattanin. The play presents Unakan as not only the disguised figure of Butsaba but also as an inner self of Butsaba or one side of Butsaba's personality which is vigorous, courageous, and self-confident.

\section{Conclusion}

From the study, Unakan is one of the Thai female characters who is extraordinary and outstanding in Thai literature because her characteristics combines images of the Thai hero and heroine. We can also see why she should be considered as the heroine as well as the hero of the story who plays the role with convincing and believable action. The heroic images of Unakan are similar to those of the Panji romances' heroines. It can be considered that the poet kept the characteristics of the Panji romances' heroines and combined them with the characteristics of the Thai heroines, thus making Unakan outstanding and different from other Panji romances' heroines.

The character might also mirror the ideal concept of woman in the late Ayutthaya to the early Rattanakosin period and has attracted Thai audiences since that time. The ability of Unakan, in addition, might have inspired the imagination of the ladies of the court who were the audience of the story.

It can be concluded that Unakan plays an important role not only in the story, but also in Thai literary tradition and Thai society.

\section{References}

Damrongrajanuphap, Somdet Phrachao Borommawongthoe. 1964.

Tamnan Lakhon Inao. Thonburi: Po. Phitsanakha Publishing.

Koster, G. L. 1997. Roaming Through Seductive Gardens Reading in Malay Narrative. Leiden: KITLV Press.

Pearson, Carol S. 1998. The Hero Within: Six Archetypes We Live By. $3^{\text {rd }}$ ed. USA: Harper Collins.

Phongsawadan Inao Chabap Arinakkhara. 1977. Translated by Khun Nikonkanprakit. Bangkok: Krom Sinlapakon.

Phutthaloetlanaphalai, Phrabatsomdetphra 2000. Rueang Inao. $14^{\text {th }}$ ed. Bangkok: Bannakhan.

Phutthayotfachulalok, Phrabatsomdetphra. 1971. Dalang. Vols.1-2. $3^{\text {rd }}$ Ed. Bangkok: Phraephitthaya.

Robson, S. O. ed. 1969. Hikajat Andaken Penurat. The Hague: Martinus Nijhoff.

Robson, S. O. 1971. Waybay Wideya A Javanese Panji Romance. The Hague: Martinus Nijhoff.

Ruengruglikit, Cholada. 2003. 'Sutsathani' nai Praratchaniphon bot lakhon nai Rueang Inao: kansuenthot lae kanphatthana. In her Wannalalit, pp. 167-229. Bangkok: Faculty of Arts, Chulalongkorn University.

Sinlapakamphiset, Plaek. 1976. Photchananukromkamphong Thai-Malayu. Bangkok: Ratchabandittayasathan. 